\title{
Islamic Policy of the Dutch East Indies Colonial Government in Madura in the First Quarter of the 20th Century
}

\author{
Iswahyudi ${ }^{1}$ \\ ${ }^{1}$ Yogyakarta State University, Yogyakarta, Indonesia \\ Correspondence: Iswahyudi, Yogyakarta State University, Yogyakarta, Indonesia.
}

Received: December 11, 2020; Accepted: January 3, 2021; Published: January 6, 2021

\begin{abstract}
At first the Dutch East Indies government policy towards Islam was wrong, because Islam in the Dutch East Indies was considered a strict religion like the hierarchical priesthood and the pope in Christianity where there was a high relationship of loyalty to the Turkish caliph, so that Islam was considered a formidable enemy. Starting with the implementation of a massive policy by the Dutch East Indies government to suppress Muslims, for example, one of them was in terms of limiting and heavier the regulations for the implementation of the pilgrimage, but in reality, regardless of the obstacles, the frequency of going on hajj was still high. Awareness of the mistakes in political policy towards Islam, the figure of Cristian Snouck Hurgronje, one of the supporters of ethical currents in the Netherlands, appeared, submitting a letter to the minister of the colonies on June 2, 1889 to participate in solving problems in the Dutch East Indies. In this case Snouk Hurgronje was the main advisor and was assisted by advisers consisting of one for Arab affairs and two experts in regional languages in the Dutch East Indies. Based on Snouck Hurgronje's advice, the Dutch colonial government distinguished between Islam in the meaning of worship and Islam as a social, social and political force. This policy towards Islam is divided into three categories, namely the socio-religious field, the socio-cultural sector, and the socio-political sector.
\end{abstract}

Keywords: Dutch East Indies government, Islamic policy, Snouck Hurgronje, Madura, Hajj

\section{Introduction}

Something that became the core discourse in the history of the colonial period, especially in the Dutch East Indies, was the significant relationship between the expansion of colonial countries and pan-Islamism. The first valve, which was related to the interests of colonialism, was when the Dutch government applied pacification politics, namely preparing policies that could cover all interests. In general, it is divided into three departments and each function is adjusted according to its geographical position. The first is the parent government based in The Hague, whose status is to focus attention on legislative issues. Second, the central government in Batavia combined legislative and administrative functions, although in carrying out its functions it was subject to general regulations that had been outlined by the central government in the Netherlands. The third was the administrative department at the local level run by officials throughout the Dutch East Indies (Van den Berg, 1900, pp. 228-269; Hurgronje, 1931, pp. 244-245).

The second valve is related to the issue of pan-Islamism, which at that time many people studied the story of the Russian war against Turkey or if in the archipelago it was known as the Rus war. This story has a big influence on the minds of Muslims who live in countries with Muslim populations. Even the people of the archipelago are eager to know about developments and every victory on the part of Sultan Rum is always remembered and celebrated accompanied by prayers and alms (Kartodirdjo, 1984, p. 209). He admitted that the Sultan of Turkey, who was said to be the legitimate ruler who could persistently defeat the infidels and Muslims were called to pray for him, allegedly because since the 1880s many scholars have spoken using a book entitled Majmu al Khatab written by Abdul Rakhman bin Ismail. bin Nabatah al Miri had a big influence on pan Islamism in the Dutch East Indies (Hurgronje, 1931, p.258). Besides the existence of the seeds of pan-Islamism, it seems that the real contribution is the formation of a broad communication system in the Islamic world which is built through the implementation of the haj pilgrimage. Related to the rise of the pilgrimage, this is an analogy with the symptoms of the Islamic renaissance which were supported simultaneously inspired by the spirit of Wahabi puritanism and furthermore by the reforms brought about by Shaykh Muhammad Abduh during the 19th century. This means that news about the Islamic community can reach the most distant places. 
Holle noted that a revival of religious life was manifesting in an increasing number of pesantren and people going on the pilgrimage. The increasing number of mosques that were erected was a sign of the increasing devotion of Muslim worship in the Dutch East Indies. Various information heard until the Dutch government was the role of a pilgrim who received honor from the Muslim community who became a follower or student (Steenbrink, 2017, p. 53).

It can be said that since the second half of the 19th century the Dutch government showed suspicion of Muslim clerics who were considered to be the instigators of various rebellions in various parts of the Dutch East Indies. This is because the traditional rulers have experienced a decline, so that the people who usually live in rural areas present new, trusted leaders, namely the kyai and hajj. With the strengthening of the community every year to go on the pilgrimage and placing Mecca as the center of Islam, it also influences the context of opposing something that is considered infidels. They opposed the authority and leadership of not only the traditional indigenous elite, but also the colonial government, which consequently felt the need to continue to observe the actions of these new leaders (Suryanegara, 1995, p. 130). In line with this the Dutch government began to adopt a new tactic by developing a special policy towards Islam.

An investigation of the general development of pan-Islamism and religious revival shows that during this period it occurred in a striking manner and was characterized by inherently anti-Western characteristics. The conquests carried out by Western imperialism are making great progress in this crucial period. Various Muslims are fully aware that the Muslim world is in danger of falling under Western domination. In the face of this threat from the West, Muslims in large parts of the Crescent Moon world display militant fanaticism that arises from feelings of hatred for the pagan conquerors (Stoddard, 1966).

The important position of Islam in people's life which is identified with nativity is to serve as the strongest expression to express loyalty to the homeland in opposing foreign invaders. This was natural if the colonial government was very suspicious of Islam and treated them specifically, namely that Islam was seen not only as a threat to security and order policies (rust end order), but also to the future of the continuation of occupation and occupation in the Dutch East Indies.

\section{Research Methods}

To find out about Islamic Policy of the Dutch East Indies Colonial Government in Madura in the first quarter of the 20th century, it was carried out using the historical method or historical research method which can be interpreted as a systematic collection of principles and rules intended to help effectively collect historical source material, in assessing or studying these sources are critical, and present a "synthesis" of the results achieved. This method is qualitative in the form of literature study using written sources from the National Archives collection of the Republic of Indonesia and libraries in the form of archives, books, journals, newspapers and other printed sources (Garraghan,1957, p. 33).

Primary and secondary data collection techniques are carried out through literature studies conducted by visiting various libraries and agencies that store written material in the form of archival material at the National Archives of the Republic of Indonesia, Jakarta, written materials in the form of monographs, magazines and newspapers published at that time in the National Library of the Republic. Indonesia and written materials in the form of reference books in other libraries. After the search for written material has been completed, the next step is to select and verify the data and compile it into writing (Iswahyudi, 2020, p.469).

\section{Colonial Government Islamic Policies in Madura}

It turned out that at first the Dutch government's policy towards Islam was wrong, because Islam in the Dutch East Indies was considered a strict religion such as hierarchical priests and popes in Christianity where there was a high relationship of loyalty to the Turkish caliph, so that Islam was considered a formidable enemy and even if necessary. the indigenous population must be Christianized (Suminto, 1985, p. 9). It is easy to Christianize the indigenous population, as in Java, that strong Islam is a santri group and others are still in syncretism with Hinduism, so that they can be divided through the politics of divide et impera.

Starting with the implementation of a massive policy by the Dutch government to pressure Muslims, for example, one of which was in terms of limiting and heavier regulations on the implementation of the pilgrimage, but in reality, regardless of the obstacles, the frequency of going on hajj was still high. Even the Dutch government increasingly realized that from 1820 to 1880 there were major rebellions, including the Padri war, the Dipanegara war, the rebellion of Banten farmers, and the Aceh war, all of which were led by religious leaders or with an Islamic background. 
Realizing the mistake in seeing Muslims in the Dutch East Indies because the special advisor on Islam and the natives, who at that time was assigned to Holle, was not good at Islamic knowledge so he had to find an appropriate replacement. Together with the victory of the Liberal party in the Netherlands or in the name of the ethics, this was to give a new direction in terms of policy in the Dutch East Indies colony. The point of this policy is to try to have humanitarian principles so that there is no glaring gap between the central government and the colony.

Awareness of the mistakes in political policy towards Islam, the figure of Cristian Snouck Hurgronje, one of the supporters of ethical currents in the Netherlands, submitted a letter to the minister of the colonies on June 2, 1889 to participate in solving the Dutch East Indies (Gobee and G. Adiaanse, 1990, p.xxiv-xxv). One year later Snouck Hurgronje came to the Dutch East Indies with his main task being to conduct research on the Acehnese tribe, and only settled in Batavia in 1892. In working activities to think about this policy, in 1899 a place was agreed to think about indigenous problems or what was called Kantoor voor Inlandsche Zaken, although physically the office was only established in 1918. In this case Snouk Hurgronje was the main advisor and was assisted by advisers consisting of one for Arab affairs and two regional language experts in the Dutch East Indies. Based on Snouck Hurgronje's advice, the Dutch colonial government distinguished between Islam in the meaning of worship and Islam as a socio-political force. This policy towards Islam is divided into three categories, namely the socioreligious field, the socio-cultural sector, and the socio-political sector.

In the socio-religious field, Snouck Hurgronje offered to change the concerns of the Dutch colonial government into an expectation. The policy towards Muslims was to allow all pure worship activities and religious rituals to be in the form of tolerance and to give as much freedom as possible. In this way it is hoped that the indigenous people will feel safe in their worship, so that they voluntarily submit to the Dutch government. Regarding social relations, one must show an attitude that seems to pay attention to Islam, one of them is by improving places of worship. It prohibited the supervision of pesantren activities that were not political in nature, and even criticized the Dutch government's actions if they hampered the implementation of the pilgrimage to Mecca. The oppression of religious adherents in carrying out worship is not only unwise, but is considered unnecessary and is considered dishonorable for a nation in the world that is embracing religious freedom as in the Netherlands (Suminto, 1985, p. 119; Benda, 1980, p. 44). In the field of Islamic law, Snouck Hurgronje offers a concept that its existence or legal strength will only be recognized when it has been accepted by the Dutch East Indies community or has become customary law. In this concept, it is intended to kill Islamic law by preserving customary law. Islamic law which is derived from Allah's revelation according to theory should cover all life with all its reality through the rules of everything (Khuluq, 1991, p. 45).

According to Snouck Hurgronje, the process of Islamization in the Dutch East Indies was not yet complete, it still had to fight against the strength of customary law which was influenced by previous religions and beliefs, so that mixing Islamic law with customary law often happened. From the two sources of law, differences of opinion as witnessed by Snouck Hurgronje among the Acehnese as well as in other regions are normal. Therefore Snouck Hurgronje took advantage of such a situation to divide Muslims and also mobilize all local rulers to support and assist groups that socially have shallow Islamic fanaticism, namely the customary chiefs, priyayi, and the abangan community (Van ' t Veer, 1985, p. 250).

However, the function of adat as a barrier to the spread of Islamic influence, which is dynamic and universal, cannot be completely relied upon. It is feared that the support for traditional customary law which continuously harms Muslims is feared to raise their awareness of hatred towards the Dutch government. In addition, the slow development of customary law was unable to fulfill long-term colonial goals, despite the fact that Islamic law was also not allowed to control customary law. According to Snouck Hurgronje, although Islam can change customs, it basically cannot evoke the higher dynamics of modern civilization. This is because Islam in the Dutch East Indies found it difficult to leave its Indian character and medieval decline. Moreover, Islamic civilization is considered to be a form of degeneration from Western-Christian civilization, so that Islam according to Western understanding cannot be used as a support for progress (Harini, 2007, p. 64).

In the socio-cultural field, Snouck Hurgronje developed the idea of association politics, which is basically about a strategy to change Muslim beliefs towards Western culture which is considered the most noble (Suminto, Aqib, H., 1985, p. 39). It was believed that this politics was the long-term goal of the colonial government, especially with regard to making the population of the Dutch East Indies modern, close to the equivalent of the West. The association politics also aimed to strengthen the ties between the colony and the central government in the Netherlands through Western-style culture and education (Benda, 1980, p.47). The association will eliminate the striking differences in political and social aspects between the indigenous population and the Dutch people and will also eliminate the ideals of Islam from all their strengths. Indirectly, association politics would also support the spread of Christianity in the Dutch East Indies. With the separation of Muslims from the spirit of their religious 
teachings, it is hoped that it can be directed to dominate Muslims without gun violence. Any tendency for the priyayi especially priyayi to associate should be welcomed and further assisted. Through education, it was hoped that the natives would be oriented towards the West and be loyal to the Dutch government. The principle of association is inseparable from the effort to win and compete with Islam for colonial preservation (Saidi, 1994, p. $59)$.

In the socio-political field Snouck Hurgronje remains vigilant on the issue of pan Islamism so that activities to stem it are continuously pursued. Although it was admitted that in practice it was not very visible in the Dutch East Indies, the suspicion of concern was still latent which could explode at any time, so that the attempt to form a modern civilization by imitating the West was one of the right choices. Related to the existence of Islam in Madura, Snouck Hurgronje is based on the Dutch missionaries and observers who have come before, including Van den Berg, Fokkens, Claerenbeck and Esser. They were always careful in making notes and reports on Madura and even being written into colonial magazine articles or neutral observers in the Dutch East Indies. In his commentary on Islam in Madura Snouck Hurgronje also suggested that there should be special attention no different from the island of Java. In addition to the increasing number of people, because if without a critical viewpoint, Madura will pose a serious threat (Hurgronje, 1994, p.50).

Snouck Hurgronje's consideration was based on the fact that Islam when brought directly by people from Hadramaut was a positive response. One example is the ruler in Sumenep, namely Sultan Paku Nataningrat who ruled from 1812 to 1854. Among those who came to Madura was Sayid Abd-ar Rahman al-Baiti, by Sultan Paku Nataningrat was appointed a teacher of Islam and Arabic for his family. . Related to this, the Sultan has a large library specifically for collections of Arabic manuscripts and Javanese literature. With the ability to speak Arabic, Sultan Paku Nataningrat often communicated with religious experts from other Hadramaut especially with Abd ar-Rahman bin Ahmad al-Misri, Abd Allah bin Somair, and Sayid Umar Baharun in Batavia to provide insight into Astronomy. Then specifically for Sayid Shaykh bin Ahmad Bafaqih was as the educator of the sultan's family. This figure was considered by Sultan Paku Nataningrat to have a reputation as a watchful sayid or ahl al-khasyf, which meant that he was an expert in predicting a person's fate (Van den Berg, 1900, p. 149).

Snouck Hurgronje also seriously considered the policies that would later be taken by the government because customary law was still strong or similar to this norm among the Madurese. In this case Van den Berg has said that not all Islamic laws must be strictly enforced but must be juxtaposed with customary law. When there is confusion between the application of customary law, Islamic law and colonial government regulations, especially those related to religious issues will be submitted to the Ulama Council. An example of this is a case that occurred in Blega village, which because it is located in an area far from the city, the management of the mosque and the population was taken over by the leader who often even served as a judge (Van den Berg, 1882, p. 29) . By giving an honorable status to the ulama, it proves that the local Madurese rulers were successful in carrying out their duties as stated in Article 17 of Government Regulation (Regering Reglement) Number. 114 in 1867, namely the supervision and order of the scholars.

Regarding other customary laws, Fokkens also reported the condition of Madura villages, especially in Sumenep and Pamekasan. At that time the perdikan villages in Madura had been imposed on the local rulers and were limited to maintaining mosques, tombs, and Islamic boarding schools, so they were considered not to endanger the Dutch government (Fokkens, 1886, pp. 441-501). When there was a burden on the local authorities, especially regarding mosques and tombs, it turned out that they had to ask for help from officials at the local level, namely the rulers and ketibs. The work of religious officials at the local level was also monitored by the Dutch government, so that in 1866 it issued a regulation which strictly prohibited village heads to regents from interfering in the collection of religious taxes. Even so, what happened in Sumenep, the rulers and headmen were suspected of corrupting them, because it was reported that a prince had withdrawn 10 rials of money for the wedding. In addition, it also attracts zakat in the form of goods, namely one rooster and two coconuts. For each Eid al-Fitr, he receives a fitrah of four catties of rice and money, and in the month of the month the victim receives 10 catties of meat, one chicken, rice and soybeans. All of that from the leader, the results are divided by ketib, so that this action is considered something burdensome for the small people in Madura (ANRI, Algemeen Verslag Regentschap Soemenep, Madoera over 1866).

Starting because of Snouck Hurgronje's miss regarding the dangerous prediction of Muslims in Madura, other tasks could be completed in Batavia. Even the Assistant Resident could approach the local Madurese rulers, namely the regents of Sumenep, Bangkalan, and Pamekasan. Apart from being local officials, they also become ulama, so that they can take over their roles. Various religious activities are also carried out, for example every Friday prayer congregation at the Jami 'mosque or the large mosque in the regency of the three regents, namely Bangkalan, Pamekasan, and Sumenep, always becomes preacher, with Arabic reading material brought by people from 
Hadramaut . In fact, especially for the regent of Sumenep, the people got the title "Sultan of Turkey". The impact that has been carried out can be said to be successful, because if the people are absent from attending congregational prayers they feel a burden of sin, so the mosque is always full (Van den Berg,1882, p.28). The source of information that stated something conducive was obtained from Claerenbeck's report, which was considered representative of the picture of Islam in rural Madura.

It is told that a man named Man Barmidin, a rich man in the village of Raun, in the Afdeeling Sumenep area, had two children named Mesi who became the wife of Mr. Haverveld, a tobacco plantation supervisor and one man named Sarim. Originally Man Barmidin was ignorant of religion and even became an opium sucker and gambler, but with his wealth he eventually became close to the ulama, so he hated the Dutch because they were considered infidels. The pilgrimage is an option just a matter of time, while Mr. Haverveld's son-in-law who is a Dutchman can still look after it well for the sake of his family. Great hope was only for his son Sarim, who was always persuaded to study religion from a scholar named Kyai Mas to become a good Muslim. At first Sarim idealized studying science from his brother-in-law Mr. Haverveld, so that he didn't seem to want to become a scholar according to his father's expectations. When the opportunity arises because Mr. Haverveld was transferred by the Assistant Resident with an assignment in Bangkalan, Man Barmidin could take over to become a large tobacco plantation entrepreneur, so that he became the richest man in his village. Furthermore, Man Barmidin also partnered with several Arab traders in Madura, so that he changed his appearance by always wearing a turban, maintaining a beard, and increasing his religious insight. Sarim was always persuaded to study religion with his friend Kyai Mas, because he was promised that after reading the Khatam Khatam would immediately be circumcised by his father, Man Barmidin. As it is known, the tradition of circumcision is a pride for Madurese boys, because they are considered adults and have the hope of getting married to their lover's girl, namely the daughter of Pa 'Mor who happens to be Man Barmidin's labor worker (Claerenbeck, 1882 , pp. 390-393).

In addition to reports or information written by some observers of the Dutch nation about the development of Islam in Madura which was not really that worrying, there were also comments that were considered negative towards the development of Islam in Madura, especially accusations at the level of religious quality. According to Esser, when he was on duty to treat the Madurese people, he had asked the people about the existence of God or Allah, but generally they could not explain. Even the word "Allah" according to them is just an ordinary word and seems to have no big meaning. It is even told that the Madurese still believe that after death their spirit will become a roaming cat. Spirits of the female gender are described as having very large breasts and function to hide small children. Then another image of evil spirits is in the form of a large white flame emitting a sound like a leaf rustling in a strong wind. There are also spirits depicted as human bodies but without backs, faces like monkeys and heads with two horns. Meanwhile, another monster image that Madurese fear is the form of two dragons that often move from place to place and then return after three months (Esser, 1882, pp. 29-30). As it is known that Esser was a Dutchman who was deliberately brought to Madura as a Zending and Mission officer, such a statement is natural because conversion to Christianity is not possible on this island. This report may also have no effect because Snouck Hurgronje considers that Islamic policy in Madura is quite conducive, based on events before his appointment as an indigenous advisor in the Dutch East Indies, especially Islam in 1889.

In relation to the socio-cultural field, as implemented by the education association in the Dutch East Indies, in this case Snouck Hurgronje was optimistic that the power of Islam would not be able to compete with Western education (Benda, 1965, p. 134). Thus the educational placement is entirely of a political nature and does not take into account that the activities of the various traditional pesantren in Madura that have previously existed are entirely moral in nature. Islamic boarding school education was not considered hierarchical in the colonial bureaucracy, but with the large number of pilgrims returning from Mecca, when they arrived in Madura they were given an honorable place to become religious teachers and were given the title of ulama or kyai. The policy of implementing Western education in the Dutch East Indies for natives had actually been since 1853, but in Madura it was first established in Sumenep in 1862, Pamekasan and Bangkalan in 1864 (Verslag van het Inlandsche Onderwijs in Nederlandsch Indie Over 1863). With this consideration because it is estimated that the Madurese population is not that enthusiastic, because it is possible that some are used to attending Islamic boarding schools and some do not know after graduating from their indigenous education. At first the Dutch government in providing indigenous education was forced to free of charge, so that the acquisition of students was not only from the aristocratic group but also the common people who were still in poverty. After it was discovered that by passing indigenous education, they were guaranteed to work for the government even though it was limited to the administrative field, the Madurese were enthusiastic and sometimes after receiving education they immediately continued to go to the Bumi Putra school. 
Table 1. Development of Indigenous Education in Madura 1900-1915

\begin{tabular}{|c|c|c|c|c|c|}
\hline \multicolumn{4}{|c|}{ Government } & \multirow{3}{*}{\multicolumn{2}{|c|}{ Subsidy }} \\
\hline & \multirow{2}{*}{\multicolumn{2}{|c|}{$\begin{array}{l}\text { School } \\
\text { Type }\end{array}$}} & \multirow[t]{3}{*}{ Student } & & \\
\hline & & & & & \\
\hline & First class & Second class & & School & Student \\
\hline 1900 & 1 & 6 & 1.335 & 1 & 50 \\
\hline 1905 & 3 & 7 & 2.024 & 2 & 106 \\
\hline 1910 & 3 & 17 & 3.347 & 2 & 216 \\
\hline $1915^{*}$ & $\begin{array}{l}\text { N.A } \\
\text { (tidak tersedia } \\
\text { data) }\end{array}$ & 27 & 4.415 & 7 & 555 \\
\hline
\end{tabular}

* There are 37 village schools with 2,431 students. In the following two decades, in 1934/1935, indigenous primary schools jumped to 231 and 23,001 students (19,493 boys, 3,508 girls).

Source: Kuntowijoyo, Perubahan Sosial Dalam Masyarakat Agraris Madura 1850 1940. Yogyakarta: Matabangsa, 2002, p. 453.

Starting from the enthusiasm of the population in getting an education, the need to establish schools continues to be carried out, even in villages including Branta, Kwanyer, and Blega. Until 1907 the village schools were only grade one and grade two with lessons given in Madura, Malay, arithmetic, and geography. The development that was considered positive for the Dutch government was the expansion of education to rural areas, because many administrative staff at the plantation or village government level were literate, thus increasing the smooth running of jobs. On the other hand, although it was never explicitly stated by the Dutch government with the progress of literacy, it also affected the Sarekat Islam movement figures, most of them were those who had received Western education (Kuntowijoyo, 2002, p.474).

\section{Solidarity for Hajj in Madura}

Regarding the number of Madurese people who have carried the title of hajj in the period before the arrival of the Dutch, so far strong and actual evidence has not been found. It was only when the colonial government had exercised its authority there that a formal policy was implemented regarding the implementation of the haj pilgrimage for the indigenous population, namely based on the Governor General's Resolution dated 18 October 1825 Number 9. In this resolution there are several requirements that must be met by residents for the purposes of carrying out worship Hajj, which is the most important thing is to have a Hajj passport or Retourbiljetten as proof of identity. If this requirement is violated, the person concerned will be subject to a fine of 110 guilders. This policy was implemented for the first time in the framework of a trial and still limited to the residents of Batavia. As it is known that since 1825 the pilgrimage was still using sailing ships or zeilschips so that the journey to Mecca was felt to be very heavy and too challenging to death because of the sea conditions which were very rough. In addition to the heavy journey in the sea, after arriving in Arab lands they still had to continue their journey from Jeddah - Mecca - Medina for 12 days and often during this journey they encountered security problems including robbers from the Baduwi tribe (ANRI. Resolutie van den Gouverneur-General. van Nederlandsch Indie van 18 October 1825, no. 9).

It was only in the middle of 1858 that the pilgrimage journey started using a steam boat or stoomschip so that it would shorten the travel time and the safety factor while at sea tended to be more secure. This of course affects the development of the increasing number of prospective pilgrims. Simultaneously with this, the colonial government used the opportunity to take advantage by participating in the haj pilgrimage transportation business by collaborating with three existing large shipping airlines, namely the Dutch shipping companies, Rotterdamsche Lloyd, and Ocean (Majid, 2008, pp. 64-66). Based on the annual report on the number of pilgrims in 1861, the increase in the number of prospective pilgrims in the Dutch East Indies reached its peak in 1858, with a total of 12,985 people (Eisenberger, 1928, p. 25). According to a report made by Jacquet, based on existing data, information about the Madurese population who for the first time departed for the pilgrimage was in 1857 with a total of 20 people, in 1858 there were 13 people and the peak in 1859 was 163 people (Jacquet, 1980, pp. 310311). They are scattered in afdeeling-afdeeling Sumenep, Bangkalan, and Pamekasan. In this case the Madura Resident also reported the status and occupation of the hajis in detail. It is said that in Pamekasan Afdeeling there are as many as seven pilgrims, all of whom work as teachers. In Afdeeling Sumenep there are as many as 71 hajj with details of 25 people who work as teachers, 19 traders, 19 farmers, 4 weaving craftsmen, and 4 fishermen. Then in Afdeeling Bangkalan there are 94 hajis with more varied work backgrounds, with details as follows; 27 
clerks, 11 farmers, 11 people or ketib, 9 teachers, 9 traders, 2 oddball traders, 8 tailors, 5 grave guards, 4 land tenants, 3 modin, 2 doctors, 1 leader, 1 priest, and 1 cattle butcher (ANRI, Politiek Verslag van Residentie Madoera over 1859).

The opening of the Suez Canal in 1879, which connected the Red Sea to the Mediterranean Sea, shortened trade routes between the Dutch East Indies and Europe. This also had a major impact on the increase in the number of hajj among the population of the Dutch East Indies so that the Dutch government became increasingly careful in handling haj pilgrimage shipping airlines. So far, residents of the Dutch East Indies who departed for the pilgrimage preferred to use British merchant ships that departed from Singapore considering the lower price. In order to avoid the monopoly competition in the handling of Hajj, the Dutch government, on the grounds of management and supervision interests, took the initiative to open a consulate in Jeddah in 1872.

As it is known that this haj pilgrimage is related to the residents of the Dutch East Indies, then the policy regarding this matter will be determined by the Minister for Colonized Land (Minister van Kolonien). With this, the government then made various policies related to the implementation of this pilgrimage and one of them was a policy to control the number of people who would carry out the pilgrimage. This policy was based on the fact that the residents of the Dutch East Indies who left for the haj pilgrimage were usually guided directly by the sheikhs and were registered as the al-Jawiyin community and were always accepted as students of Middle Eastern scholars. The government considered this as the potential for them to be affected by various negative influences that were detrimental to the interests of the colonial government. In addition, the government in order to suppress and supervise hajj activities also issued Staatsblad 1898, Number. 294 or as an ordinance for the implementation of hajj related to embarkation by determining special hajj ports in Batavia and Padang (Staatsblad van Nederlandsch Indie, 26 October 1898. no. 294). The placement of the two ports made it easier for the Dutch government to monopolize and arrange pilgrimage trips because since 1885 the number had increased to $61 \%$ of pilgrims using ships owned by Dutch ship companies. Actions to complicate the implementation of the pilgrimage seem as if they were made irrationally, one of which is by carrying out a health check both at the time of the Hajj departure and return.

The increasing number of people who go to perform the pilgrimage to Mecca is a dilemma for the government, resulting in a kind of ambiguity from various parties to make policies based on political and economic considerations. In this case, the political consideration is that the residents there will be able to communicate freely with their communities through various meetings with ulama so that it is considered to be able to instill the embryo of radicalism, especially the pan-Islamic movement of the Sultan of Turkey. Starting from this, strict health requirements are applied so that many of them who are old will not be able to pass this examination and cancel their intention to carry out the pilgrimage. Regarding this, Saidin, a prospective pilgrim from Pamekasan, had to carry a verbal process containing a medical certificate signed by Haji Mohammad Rusli, an official of the Pamekasan wedana, which is evidence of the strict administrative requirements for carrying out the pilgrimage. Then as an economic consideration is because until 1895 the cost of carrying out the hajj that departed directly from the Dutch East Indies to Jeddah was f. 283, - with details of f.120, - only for boat tickets. With this huge potential for profit, related to this Haj policy, every Resident Assistant in his area always asks all regents to promote to the population in exchange for a commission fee of f.2.50, - for each prospective Hajj (ANRI, Hajj Travel Bureau in Colonial Indonesia Agent Herklots and Firm Alsegoff \& Co., 2001).

With a fee of f. 283, - for one person the Hajj candidate is actually too big for the Madurese population because in general the population only depends on the crops of rice and tobacco on agricultural lands which are categorized as less fertile land. This is different from other regions whose agricultural and plantation business conditions are classified as advanced so that their economies are developing. In these areas, for example, the clove crop in 1890 could be sold at a price of f. 50, - for every kilogram. With this, the residents there will feel easy to pay the cost of carrying out the pilgrimage because it is only equivalent to the yield of 10 kilograms of cloves. In reality, the Madurese interpreter the Hajj as a choice that can provide high motivation. So far, it has been recognized that the Madurese are known as people who are resilient, resilient and able to work hard. This is evidenced by the fact that since the early nineteenth century the Madurese people often reported going to migrate to work to the island of Java either temporarily or permanently living as laborers in plantations and in other informal fields (Kuntowijoyo, p. 75; Ahmad Sukri and Agus Himmawan Sutomo, 2001, p. 14-15; Rahman, 1990, p. 11-12).

Starting from the high enthusiasm of the Madurese people to obtain the status of Hajj, this is reflected in the number of pilgrims from Madura who in 1930 showed the highest number compared to other areas in East Java. However, after 1930 this number, as in other areas in the Dutch East Indies, gradually decreased. One of the causes of this decline was as a result of the world economic depression which at that time hit both the Dutch East Indies and other countries. The impact of this economic depression was also felt by the Madurese, although it was not as 
severe as other areas outside Java (Vredenbregt, 1997, p. 29). Besides that, the decline was also caused by weather factors because in the 1930s Madura there was a long dry season which resulted in a major decline in agricultural production.

Table 2. Pilgrims from Madura Residency

\begin{tabular}{cll}
\hline Year & Number of pilgrims & Explanation \\
\hline $1913-1915$ & 2.692 & World War I period 1914-1918 \\
$1916-1920$ & - & \\
$1921-1923$ & 4.095 & The Hejaz war and the pilgrimage were halted \\
$1924-1925$ & - & No source found \\
$1926-1929$ & - & \\
$1930-1931$ & 1.589 & \\
$1932-1935$ & 986 & \\
$1936-1939$ & 852 & \\
\hline
\end{tabular}

Source: Data for the years 1913-1915, 1921-1923 taken from J.W Meyer Ranneft, Onderzoek naar de Belastingdruk op de Inlandsch Bevolking van Java en Madoera (Weltreveden: Landsdrukkerij, 1926), p. 155. Data for 1916-1920 is from Dick Douwes and Nico Kaptain (ed), Indonesia dan Haji (Jakarta: INIS, 1997), and data for the years 1930-1939 is taken from the Indische Verslag 1931-1941

Table 3. Comparison of the number of hajj in Madura and East Java in the years 1930-1938

\begin{tabular}{lll}
\hline Year & Number of Madurese Hajj pilgrims & Number of East Java Hajj Pilgrims \\
\hline 1930 & 1.037 & 4.019 \\
1932 & 359 & 1.293 \\
1933 & 155 & 526 \\
1934 & 159 & 579 \\
1935 & 313 & 818 \\
1936 & 152 & 704 \\
1937 & 139 & 818 \\
1938 & 344 & 1.530 \\
\hline
\end{tabular}

Source: 1930 data from the 1933 Indische Verslag, p. 110. 1932 data from the 1935 Indische Verslag, p. 113. Data for 1933-1936 from the 1937 Indische Verslag, p. 119. and the 1938 data from the 1939 Indische Verslag, p. 139.

Based on the table above, it can be explained that in general the largest number of prospective pilgrims for the pilgrimage in the Dutch East Indies came from residents living in Java and Madura. Madura in this case is actually also included as a residency area in East Java, in which case the largest number of people who carry out the Hajj pilgrimage. Regarding the number of these figures, there is actually no complete data for each year due to various administrative constraints, such as data on residents leaving for the haj pilgrimage and data on residents who returned, not always reported by colonial government officials who were authorized to take care of this. According to Kuntowijoyo, up to 1885 there were 1,111 people holding hajj in Madura. The number of $\mathrm{i}$ in 1890 increased to 1,364 people. Then in 1895 alone, there were 603 Madurese who went to Mecca to perform the haj pilgrimage (Kuntowijoyo, 2002, p. 334).

Furthermore, during the World War I, in 1914, it had a big impact on the departure of the prospective pilgrims because the conditions and situations of international shipping were not conducive. The decline in the hajj activity for several years generally also applies in many countries outside the Dutch East Indies (Ranneft and W. Huender, 1925, p. 155). With the end of World War I, it was not until 1919 that the situation and conditions for international shipping were in a conducive state to return to normal so that the activities of the population to carry out the pilgrimage could return to the same as in previous years. In 1920, the number of people performing the Hajj pilgrimage began to increase again, as well as in Madura, it was recorded that the number of people who left for Hajj in 1921, 1922, and 1923 reached 4,095 people (Vredenbergt, 1997, p. 56). The increase in the number of pilgrims is understandable because in previous years, during World War I, the pilgrims did not depart for the reasons mentioned above. This postponement that occurred for several years certainly had an impact on a significant increase in the number of Hajj in 1919 and the following years. 
In 1924 the number of people carrying out the pilgrimage experienced a sharp decline and the number became very small. Of the entire territory of the Dutch East Indies, only 74 people departed for the pilgrimage to Mecca. This was mainly due to the fact that in that year there was an internal conflict in the Arabian Peninsula, namely the war between the Bani Saud as rulers of the Nejd region in the interior with Bani Hashim from the Hejaz region on the Red Sea. The situation returned to normal in 1926, where this year it is known that the number of pilgrims from the Dutch East Indies reached 52,412 people. This number is the highest compared to previous years, and it is even stated that this number reached 42.6 percent of all world pilgrims who left for the Arabian Peninsula that year (Nagazumi, 1996, p. 211; Vredenbergt, 1997, pp. 56-58).

The increase in the number of pilgrims from the Dutch East Indies can be attributed to, among other things, Ibn Saud's victory in Mecca. It is said that after successfully conquering Medina and Jeddah on January 4, 1927, then Ibn Saud officially became the ruler in Jeddah. As a Wahhabi follower, Ibn Saud strives to restore peace, one of which is to give freedom to the world's Muslims to perform the Hajj accordingly. It is suspected that along with the economic improvement in the Dutch East Indies, especially in the agricultural sector, it had an impact on increasing prosperity, so many Dutch Indies people had time to save money to go for the pilgrimage. As evidence in 1930 the number of pilgrims in Madura reached 1037 people, in that year the number of Madurese pilgrims was the highest in East Java. (Suminto, p. 205). Then in 1931 the candidates for the Madura pilgrimage experienced a decline, even more or less half of the number of the previous year. Likewise in 1932, 1933 and 1934 the number of Madurese pilgrims continued to decline and showed an increase in 1935 then decreased again in 1936 and 1937 (ANRI, Indische Verslag 1935, 1937, 1939).

\section{Development of Population Education and Islamic Scholarship}

The positive impact of the increase in the number of pilgrims, especially in Madura, is the development of Islamic boarding schools and similar religious schools. Pesantren is a typical indigenous educational institution and can be found in Madura. In terms of the model, it seems that the pesantren in Madura tend to follow the pattern of the pesantren in Java (Kuntowijooyo, 2002, p. 195). Since the arrival of the Dutch, the pesantren which were originally located in urban areas then moved to rural areas. In the mid-19th century the government had succeeded in controlling all coastal areas in Java and succeeded in exploiting the sea trade, so that life in the cities was controlled by the Dutch. The movement of the Islamic boarding schools to rural areas resulted in isolated teaching materials. The limitations of the subject matter provided by the pesantren, can be understood given the tight isolation that Muslims at that time did not have sufficient opportunities to interact with the outside world. It seems that the life and development of Islamic education also depends on the materials owned by the teachers. Pondok pesantren is a representation of the Islamic education system that existed at that time. It was only when maritime relations between the European continent and Asia developed due to the influence of the opening of the Suez Canal in 1869 that new enthusiasm and motivation in religious life emerged among the population of the Dutch East Indies. This is due to the influence of the increasing number of hajj, Koran teachers and pesantren students as well as the awareness to oppose government power (Asifudin, 1994, p. 56).

The increase in the growth of the hajj and the importance of the role of hajj at the end of the 19th century contributed to the improvement of the education system among the Muslim population and was local in nature because it was able to provide effective communication demarcation between pesantren and the international community, especially Mecca as the center of Islamic civilization (Geertz, 1960, p. 232). Many young people from the archipelago then lived and studied in Mecca and Medina and not only for the purpose of performing the pilgrimage. Not a few of them managed to become famous scholars and became teachers there. It turned out that they also took an active role in the development of thought and spiritualism centered there and in turn had an influence and gave a color to the development and change in the characteristics of Islamic understanding in the archipelago. Thus the teaching in the pesantren in the Dutch East Indies was heavily influenced by the teaching system in Mecca.

Likewise, what happened in Madura at the end of the 19th century where the number of Kyai increased in number along with the large number of pilgrims. The economic surplus experienced by the rural population helps religious leaders to provide religious education in a more organized and orderly manner. Religious figures, especially those directly involved in organizing education and religion, seem to gain the sympathy of the villagers as potential independent leaders. Although the Kyais generally never become independent in reaching their supporters, they have succeeded in positioning themselves as internal critics who can counterbalance foreign powers who do not want them to become pilots for change. The rural population recognizes and models their personality as a symbol of their independent nature, even until the next period the role of Kiai in Madura can be categorized into four types, namely pesantren kiai, tarekat kiai, political kiai, and stage kiai (Sukamto, 1992, pp. 76-77). 
The categorization of the role of the kiai is a reflection of the group of pilgrims in Madura who have succeeded in forming an important social layer in society. Although only a small proportion of the hadjis actually studied Islam more systematically, the increasing number of them could strengthen this religious elite group (Mansurnoor, 1990, p. 55). Regarding the development of the pesantren played by the Kiai, especially in Madura all Kiai are considered to be descendants of Sunan Giri so that they gain very strong legitimacy. For example, several Islamic boarding schools that are considered as old Islamic boarding schools in Madura include the Banyuanyar Pamekasan Islamic boarding school which was founded by kiai Haji Itsbat ibn Ishaq in 1788, the Demangan or Syaikhona Kholil Islamic boarding school which was founded by Mohammad Kholil in Bangkalan in 1861. Then the An- Islamic boarding school Nuqayah in Guluk-Guluk Sumenep which was founded by Kiai Haji Mohammad Syarqowi in 1887 (Aboebakar, pp. 41-42).

These old Islamic boarding schools can inherit the growth of the next boarding schools, both salafi and kalafi, so that until now Madura has been dubbed the "Island of a Thousand Islamic Boarding Schools". Soebahar said that by tracing data through the Eductional Management Information System (EMIS) found in the head of the section of religious education and Islamic boarding schools (Kasie Pekapontren) in each district office of the Department of Religion, the following data were obtained: 258 pesantren in Bangkalan district, 181 pesantren in Sampang district, 462 pesantren in Pamekasan district, and 224 pesantren in Sumenep district. The number of pesantren in the four Madura districts is 1,125 Islamic boarding schools (Soebahar, 2008, p. 45).

The inheritance system given to Islamic boarding schools which is still strong for all time is mainly covering all classical Islamic books which in this case can be grouped into six (Dhofier, p.50). Among them are language, the Koran, hadith, monotheism, jurisprudence, and tasawwuf. More on this matter can be explained as follows. The language component for Arabic is presented with the material nahwu (imriti and Nahw al-Wadih), sarraf(Amtsilat al-Tasrifiyyah, Matnulbina, Kailani, Alfiyah Ibn Malik, Mutammimah), balaghah, and mantiq. The components of the Koran consist of: qiraat (tajwid, Hidayatus Sibyan, Tuhfatul Aftal, Hidayatul Mustafid, Mursyidul Wildan, and Syifaur Rahman), tafsir (Jalalain Maraghi, translation, and Ulum al-Quran. The hadith components consist of: matan hadith (Arbain) al-Nawawi, Mukthar al-Hadith, Bulugh al-Maram, Jawahir al-Bukhair) and Ulum al-Hadits (Minhaju al-Mughits).

The components of tauhid consist of: aqaid 50 and kalam knowledge taken from the book Kifayatul 'Awam, Aqidah Islamiyah, Jawahir al-kalamiyah, Tuhfatul Murid, and Husn mal-Hamidiyah. The fiqh components consist of: fiqh, proposed fiqh and qawaid al-fiqh taken from the books of Safinah al-Najah, Matan Taqrib, Minhaj alQawim, kifayah al-Akhyar, Sullam, Fath al-Muin, and Waraqat. The components of Sufism consist of: behavioral tasawwuf, knowledge tasawwuf, and organizational tasawwuf (tareqat) which refer to the book al-Wasaya al-Abna, Ta'lim al-Muta 'allim, Minhajul' Abidin, Irsyadul 'Ibad, and Risalah al-Mu 'Cloudah wa al-Easyarah wa alMuwazarah.

In addition to the classical Islamic book or the Yellow book, it turns out that in its development, many Madurese scholars have also become Islamic intellectuals because it is evident from the many products of their work and it is suspected that they are still stored both in Islamic boarding schools and as private collections. Starting with the prolificity of the scholars is proof of the solidarity of the hajj in Madura because they often use each other among the distribution of these works for learning materials in the pesantren they teach. These works can be in the form of original, hasyiyah, syarah, translation, and khulasah works. An original work is a work written by scholars both in Arabic and in local languages such as Madurese. Hashiyah is a kind of explanation or information written on the edge of a book and generally can be a commentary on the existing text before and the text that has been given hasyiyah is printed on the edge of the book page. Sharah is a commentary book both in Arabic and in the regional language against older texts (matan) and text that has been commented on by being printed on the margins of the book. Translation is a copy or translation of language from one source language to the target language. In this context, the translation is the result of translation from one Arabic language into Indonesian or the local Madurese language, for example, Khulasah is a summary of the work of other scholars which contains the main material in order to facilitate the reader's understanding.

The works of Madurese scholars up to now that can be perfectly inventoried are those in the Bangkalan and Sampang groups. Then the Sumenep group was not well inventoried because it was still handwritten and was also scattered in people's homes. Various works of scholars in Sumenep are only told of as many as 47 works found. Of these 7 of them are the work of K.H. Habibullah Ro'is, 2 by K.H. Nawawi Tibyan, 2 by Syeh Muhammad Ilyas bin Muhammad Syarkawi, 32 by K.H. Thopur bin Aliwafa bin Muharor Al Maduri, 2 by KH. Gofir, 1 by K.H. Abdullah Kholil, and 1 by K.H. Mahmudi Syukri. Until now, these works are scattered in the Sumenep area, especially in the Al-Is'af Islamic boarding school, the Assadad Islamic boarding school, and the Al Usymuni Islamic boarding school. Islamic boarding school Al-Is'ap dominates the field more; nahwu, nerves, fiqh, language, 
mantiq, balagho, hushul, faroid, tauhid, and morals. The Assadad Islamic boarding school is master in the field of expertise; figh, nahwu, language and literature, history, methods of Arabic songs, Sufism, and tafsir. Then the AlUsymuni Islamic boarding school mastered the field; tafsir, hadith, jurisprudence, nerves, and nahwu (Yunardi et al., 2011, pp. 33, 129). When viewed from the side of the content, the works of these scholars can be further grouped into 10 fields of study as can be seen in the table below.

Table 4. The work of the Ulama in Sumenep is seen from the field of study

\begin{tabular}{lll}
\hline Number & Field of study & Amount \\
\hline 1 & Jurisprudence (Fikih) & 24 \\
2 & History (Sejarah) & 7 \\
3 & Tawheed (Tauhid) & 5 \\
4 & Morals (Akhlak) & 3 \\
5 & Language (Bahasa) & 2 \\
6 & Sufism (Tasawuf) & 2 \\
7 & Nahwu & 1 \\
8 & Hutbah & 1 \\
9 & Faroid & 1 \\
10 & Guide (Panduan) & 1 \\
& Amount & 47 \\
\hline
\end{tabular}

Source; Badri Yunardi (et.al), Inventarisasi Karya Ulama Di Lembaga Pendidikan Keagamaan: Studin Kasus Provinsi Jawa Timur (Jakarta: Puslitbang dan diklat Kementrian Agama, 2011).

Based on the table, among the 10 fields of study, when viewed from a scientific perspective, it shows that the books of the three scholars are diverse. From all these works, it turns out that until now it is still used as a compulsory handbook for santri in their respective Islamic boarding schools. Starting from the table, scholars or kyai from three Islamic boarding schools in Sumenep did not write their works in one language but poured it into four languages and the most dominant was Arabic. Regarding the form in expressing the works of the scholars, there are various methods. Some are really their own or pure ideas. There are also those who are inspired by mensyarah (description of the previous book), summarize, and comment or ta'liq. Thus the works of these scholars can be understood by the next generation, especially users in understanding Islam to be practiced and implemented in daily life without being separated from the rules that have been determined in the Al-Quran and sunnah.

\section{Conclusion}

It can be said that since the second half of the 19th century the Dutch government showed suspicion towards Muslim clerics who were considered to be the instigators of various rebellions in various parts of the Dutch East Indies. This is because the traditional rulers have experienced a decline, so that the people who usually live in rural areas present new, trusted leaders, namely the kyai and hajis. With the strengthening of their community that has carried out the haj pilgrimage and has placed Mecca as the center of Islam, it also influences the context of opposing something that is considered kafir. They opposed the authority and leadership of not only the traditional indigenous elite, but also the colonial government, which consequently felt the need to keep a close watch on the actions of these new leaders. In line with that the Dutch East Indies government began to apply new tactics by developing a special policy against Islam among the population, including the Madurese population.

The important position of Islam in the life of the Madurese, which is identified with nativity, is to function as the strongest expression of loyalty to the homeland in opposing foreign invaders. This was natural if the colonial government was very suspicious of Islam and treated them specifically, namely that Islam was seen not only as a threat to security and order policies (rust end order), but also to the future of the continuation of occupation and occupation in the Dutch East Indies. In this case Snouk Hurgronje was the main advisor and was assisted by advisers consisting of one for Arab affairs and two experts in regional languages in the Dutch East Indies. Based on Snouck Hurgronje's advice, the Dutch colonial government distinguished between Islam in the meaning of worship and Islam as a socio-political force. This policy towards Islam is divided into three categories, namely the socio-religious field, the socio-cultural sector, and the socio-political sector.

In the socio-religious field, Snouck Hurgronje offered to change the concerns of the Dutch colonial government into an expectation. The policy towards Muslims was to allow all pure worship activities and religious rituals to be in the form of tolerance and to give as much freedom as possible. In this way it is hoped that the indigenous 
people will feel safe in their worship, so that they voluntarily submit to the Dutch government. Regarding social relations, one must show an attitude that seems to pay attention to Islam, one of them is by improving places of worship. It prohibited the supervision of pesantren activities that were not political in nature, and even criticized the Dutch government's actions if they hampered the implementation of the pilgrimage to Mecca. The oppression of religious believers in carrying out worship is not only unwise, but is considered unnecessary and is considered dishonorable for a nation in the world that is embracing religious freedom as in the Netherlands. In the field of Islamic law, Snouck Hurgronje offers a concept that its existence or legal strength will only be recognized when it has been accepted by the Dutch East Indies community or has become customary law.

\section{References}

ANRI, Algemeen Verslag Regentschap Soemenep, Madoera over 1866.

ANRI. Resolutie van den Gouverneur-General van Nederlandsch Indie van 18 October 1825, no. 9.

ANRI, Politiek Verslag van Residentie Madoera over 1859.

ANRI, Biro Perjalanan Haji di Indoneasia Masa Kolonial. Agen Herklots dan Firma Alsegoff \& Co, 2001

ANRI, Indische Verslag 1931 - 1941 Staatsblad van Nederlandsch Indie, 26 Oktober 1898. no. 294

Aboebakar, H., Sedjarah Hidup K. H. A. Wahid Hasjim dan Karangan Tersiar (Djakarta: Panitya Buku Peringatan Alm. K.H.A. Wahid Hasjim)

Ahmad Sukri, Ridwan and Agus Himmawan Sutomo, "Studi Etika Pandangan Hidup Dalam Fenomena Budaya Merantau Pada Masyarakat Madura" in Lembaga Penelitian Universitas Gadjah Mada, (Yogyakarta: LemLit, 2001), pp. 14-15.

Asifudin, Ahmad Janan (1994). Pondok Pesantren Dalam Perjalanan Sejarah. Al Jamiah, 5, p. 56.

Benda, Harry J. (1965). Continuity and Change in Indonesian Islam”, in Southeast Asian Studies (Yale University: New Haven, 1965).

Benda, Harry. J., Bulan Sabit dan Matahari Terbit (Jakarta: Pustaka Jaya, 1980).

Claerenbeck, J. (1882). Sarim en Kansina: Eene Schets uit het Madoereesche Dorpsleven. Eigen Haard, 33, 390393.

Dhofier, Zamaksyari, (1982). Tradisi Pesantren: Studi tentang pandangan hidup Kiai. Jakarta: LP3ES, 1982.

Douwes, Dick and Nico Kaptain (ed), Indonesia dan Haji (Jakarta: INIS, 1997) Effendy, Bisri, An Nuqayah: Gerak Transformasi Sosial Di Madura (Jakarta: P3M, 1990).

Eisenberger, J. (1928). Indie and de Bedevaart naar Mekka (Leiden: M. Dubbeldemen, 1928).

Esser, J. P. (1882). Onder de Madoereezen (Amsterdam: Hoveker \& Zoon, 1882).

Fokkens, F. (1886). "Desa's op Java en Madura" in Tijdschrift voor de Indische Taal-, Land- en Volkenkunde Bataviaasch Genootschap van Kunsten en Wetenshappen, 31, 441-501.

Garraghan, G. J. (1957). A Guide To Historical Method. (New York: Fordham University Press, 1957).

Geertz, Clifford (1959-1960). The Javanese Kjiai The Changing Role of Cultural Broeker. Comparative Studies in Society And History, 2, p. 23. https://doi.org/10.1017/S0010417500000670

Gobee, E., \& Adiaanse, G., \& Nasehat, C. (1990). Snouck Hurgronje Semasa Kepegawaiannya Kepada Pemerintah Hindia Belanda 1889-1936, Translated by Sukarjo (Jakarta: INIS, 1990).

Harini, Islam di Indonesia: Studi Tentang Pandangan Snouck Hurgronje, Unpublished thesis (Yogyakarta: Jurusan Ilmu Perbandingan Agama, Fakultas Usuludin, UIN Sunan Kalijaga, 2007).

Hurgronje, C. Snouck (1931). Mekka in the Latter Part of the $19^{\text {th }}$ Century. Daily Life, Customs and Learning. The Moslims of the East-Indian Archipelago, (Leiden and London:tp, 1931).

Hurgronje, C. Snouck (1973). Islam di Hindia Belanda, terjemahan (Jakarta: Bhatara, 1973).

Hurgronje, C. Snouck. Kumpulan Karangan, Translated by Sutan Maimun dan Rahayu, S. Hidayat (Jakarta: INIS, 1994).

Iswahyudi (2020). The Implementation of the Cultuurstelsel in Java: Cases in Afdeeling Demak and Grobogan, Central Java versus in Afdeeling Pacitan, East Java 1830-1870". Britain International of Humanities and Social Sciences (BIoHS) Journal, 2(3), 657-668. https://doi.org/10.33258/biohs.v2i3.316

Jacquet, F. (1980). Mutiny en Haji-Ordonnantie Ervaringen met 19e eeuwse Bronnen. Land-en Volkenkunde, 136, 
310-311. https://doi.org/10.1163/22134379-90003526

Kartodirdjo, Sartono (1984). Pemberontakan Petani Banten 1888 (Jakarta: Pustaka Jaya, 1984).

Khuluq, Latiful Cristian Snouck Hurgronje dan Pemikiran Tentang Islam di Indonesia, Unpublished thesis Fakultas Adab IAIN Sunan Kalijaga Yogyakarta, 1991).

Kuntowijoyo, Perubahan Sosial Dalam Masyarakat Agraris Madura 18501940 (Yogyakarta: Matabangsa, 2002).

Majid, M. D., Berhaji, Di Masa Kolonial (Jakarta: CV Sejahtera, 2008).

Mansurnoor, Lik Arifin, Islam in An Indonesian World: Ulama of Madura (Yogyakarta: Gadjah Mada University Press, 1990).

Nagazumi, A. (1996). Pemberontakan PKI 1926 dan Perkembangan Jemaah Haji Indonbesia. In Akira Nagazumi (ed), Indonesia Dalam Kajian Sarjana Jepang: Perubahan Sosial Ekonomi Abad XIX - XX dan Berbagai Aspek Nasionalisme Indonesia. Jakarta : Yayasan Obor Indobesia, 1996.

Rahman, Bustami (1990). Naik Haji: Persepsi dan Pelaksanannya Bagi Orang Madura Di Jember, Jawa Timur”, in Bidang Kajian Madura (Jember: Universitas Jember, 1990), 11-12.

Ranneft, J. W., Meyer \& Huender, W. (1925). Onderzoek naar de Belastingdruk op de Inlandsche Bevolking van Java en Madoera (Weltreveden: Landsdrukkerij 1925).

Saidi, Ridwan, (1994). Fakta Islam Data Yahudi di Indonesia Serta Opkkasi Kaum Peasternis, Orientalis dan Spionace Intelektual Snouck Hurgronje Di Indonesia, jilid II (Jakarta LSIP, 1994).

Soebahar, Abdul Halim (2008). Pondok Pesantren Di Madura: Studi Tentang Proses Transformasi Kepemimpinan Akhir Abad XX. Unpublished dissertation UIN Sunan Kalijaga Yogyakarta, 2008).

Suminto, H. Aqib (1985). Politik Islam Hindia Belanda (Jakarta: LP3ES, 1985).

Steenbrink Karel A. (2017). Kaum Kolonial Belanda dan Islam di Indonesia(1596-1942). Yogyakarta: Gading Publishing, 2017.

Stoddard, L. (1966). Dunia Baru Islam (Jakarta: Panitia Penerbit, 1966).

Sukamto, (1992). Kepemimpinan Kiai dan Kelembagaan Pondok Pesantren , Tesis tidak dipublikasikan. unpublished thesis Universitas Gadjah Mada Yogyakarta, 1992.

Suryanegara, Ahmad Mansyur (1995). Menentukan Sejarah: Wacana Pergerakan Islam di Indonesia (Bandung: Mizan, 1995).

Syaiful Bakhri, Mokh (2006). Syaichona Cholil Bangkalan Ulama Legendaris Dari Madura (Sidogiri Kraton Pasuruan: PT Cipta Pusaka Utama, 2006).

Syamsul Arifin, Muhammad (1991). Sejarah Singkat Pondok Pesantren Banyuanyar (Banyuanyar: PP Darul Ulum, 1991).

Verslag van het Inlandsche Onderwijs in Nederlandsch Indie Over 1863 (Batavia: Landsdrukkerij, 1865), pp. 188189.

Van den Berg, L. W. C. (1900). Het Pan Islamisme. De Gids, Serie IV. Vol LXIV, 1900, pp. 228-269.

Van den Berg, L. W. C. (2010). Orang Arab di Nusantara. Translated by Rahayu Hidayat. Jakarta: Komunitas Bambu, 2010.

Van den Berg, L. W. C. (1882). De Mohammedaansche Geestelijkheid en de Geestelijke Goederen op Java en Madoera", in Tijdschrift voor Indische Taal-Land-en Volkenkunde, Deel XXVII, Bataviasche Genotschap, 1882, p. 29.

Van't Veer, Paul, Perang Aceh, Kisah Kegagalan Snouck Hurgronje, Translated by Grafiti Pers (Jakarta: Grafiti Pers, 1985).

Vredenbregt, Jacob (1997). Ibadah Haji Beberapa Ciri dan Fungsinya di Indonesia", in Dick Douwes and Nico Kaptain (ed), Indonesia dan Haji (Jakarta: INIS, 1997).

Yunardi, Badri et al. (2011). Inventarisasi Karya Ulama Di Lembaga Pendidikan Keagamaan: Studi Kasus Provinsi Jawa Timur (Jakarta: Puslitbang dan diklat Kementrian Agama, 2011). 


\section{Copyrights}

Copyright for this article is retained by the author(s), with first publication rights granted to the journal.

This is an open-access article distributed under the terms and conditions of the Creative Commons Attribution license (http://creativecommons.org/licenses/by/4.0/). 